\title{
Lagöverträdelse och samhällsingripande
}

\author{
Av professor ALVAR NELSON, Uppsala
}

\section{Samhällsingripandets former}

Den svenska processlagstiftningen innehåller en allmän princip om absolut åtalsplikt men principen har successivt urholkats genom alltmera omfattande undantag. Det var därför icke ägnat at förvåna, att regeringen år 1970 fann tiden vara inne att pröva hela frågan om åtalsunderlåtelse. I direktiven till åtalsrättskommittén (Riksdagsberättelsen år 1971, Ju 55) utvecklade justitieminister Lennart Geijer sin syn på förutsättningarna för en avsevärt vidgad användning av möjligheten att underlåta åtal och anförde därvid bl. a. följande:

Om kriminalpolitiska och processekonomiska synpunkter får ökad betydelse i brottmålsprocessen fảr målsägandens intresse av att straffansvar utkrävs ett minskat utrymme.

En särskild fråga i samband med åtalsunderlåtelse är vilka krav som kan ställas på bevisningen för att åtal skall kunna underlåtas. Det kan visa sig, att de nuvarande kraven på fullständig bevisning vid beslut om åtalsunderlåtelse bör modifieras.

De grundläggande reglerna om åtalsunderlåtelse finnas i 20:7 rättegångsbalken (RB) med supplerande bestämmelser i 1 § 1964 års lag med särskilda besiämmelser om unga lagöverträdare (LUL), 69 § 1960 års barnavårdslag (BvL) 57 § 1954 års lag om nykterhetsvård (NvL) och $21 \S 1964$ års redan obsoleta lag om åtgärder vid samhällsfarlig asocialitet (AsocL).

Utöver dessa stadganden om åtalsunderlătelse finnas i brottsbalken ( $\mathrm{BrB})$ särskilda regler, enligt vilka åtalsprövning enligt angivna förutsättningar skall företagas. Såsom 1968 års brottsmålsutredning framhållit (SOU 1971:10, s. 133) torde det numera vara klart, att det är möjligt för åklagaren att utan närmare utredning fatta beslut om att åtal icke skall verkställas i fall, där en sådan åtalsregel finnes. I praktiken avskrivas också mål, där åtalsprövning kan ifrågakomma, i betydande omfattning och i många fall redan på anmälningsstadiet.

Som grundval för beslut att icke tala å brottet ligger för åklagaren en förundersökning, annan polisutredning eller i vissa fall blott en anmälan från målsäganden eller allmänheten. I själva verket når emellertid många bagetellförseelser aldrig fram till åklagarens bord. Av gammalt har polisen ansetts ha befogenhet att meddela rapporteftergift på platsen eller att underlåta att vidarebefordra rapport till åklagaren (rapporteftergift i efterhand). En bestämmelse härom finnes numera i 1965 års polisinstruktion (PI). 
Den stora rättegångsreform som ledde fram till RB (i kraft âr 1948) gav också upphovet till vissa summariska strafförfaranden, enligt vilka annan myndighet än domstol kunde förelägga den felande att betala ett bötesbelopp. Först kommo reglerna om strafföreläggande, nu i 48:4-12 RB och senare bestämmelser om föreläggande av ordningsbot (ofta kallat ordningsföreläggande), numera i 48:13-20 RB. Vid sidan av dessa stadganden finnas i 1960 år lag om parkeringsbot bestämmelser om anmaning att betala parkeringsbot. Gemensamt för dessa summariska förfaranden är, att man därigenom i högst betydande utsträckning undgår att belasta domstolarna med bötesmål.

Mycket schematiskt kan man redovisa de olika myndigheternas handläggning av mål och ärenden rörande brott och lagbrytare på följande sätt:

Rapporteftergift

Rapporteftergift

i efterhand

Åtalsunderlåtelse Åtalsprövning

Påföljd ej ådömd
Polismans bedömning

Polisrapport

Polisbefäls bedömning Utredning

Åklagarens bedömning Åtal väckes Domstolens bedömning
Anmaning att betala parkeringsbot Föreläggande av ordningsbot

Föreläggande av ordningsbot

Strafföreläggande (Föreläggande av ordningsbot)

Påföljd ådömd

Genom den i korthet skisserade utvecklingen har den situationen uppkommit, att elit och samma brott - vanligen en lindrigare lagöverträdelse - kunnat ge upphov till rapporteftergift hos polisen, beslut att icke tala å brottet hos åklagaren och domstols avgörande, att påföljd icke skall ifrågakomma, eller till summariskt strafförfarande eller domstols avgörande, att påföljd skall ifrågakomma. Det är väl tänkbart, att myndigheterna och domstolarna icke ha samma uppfattning om den rätta samhällsreaktionen för samma brott. Dessa svårigheter ha icke varit statsmakterna obekanta, men man har ansett, att betydande processekonomiska vinster varit att vinna både för samhället och den enskilda lagöverträdaren.

Med rätta ha statsmakterna upprepade gånger uppmärksammat de rättssäkerhetsproblem, som följa med en handläggning av mål och ärenden rörande brott och lagbrytare utanför domstolarna. I samband med fråga om ändring av straffsatserna för vissa trafikförseelser och av formerna för handläggningen av 
mindre brottmål gjorde dåvarande justitieministern Herman Kling mot bakgrund av ett av trafikmålskommittén avgivet betänkande (SOU 1963:27) vissa generella uttalanden (i proposition $\mathrm{nr} 100$ år 1966):

Allmän enighet råder om att domstolsförfarandet ger de starkaste garantierna för ett materiellt riktigt avgörande. Redan vid rättegångsbalkens tillkomst framhölls emellertid att det ordinära domstolsförfarandet är anpassat för betydelsefulla och invecklade mål samt att det skulle vara alltför betungande för den misstänkte och medföra onödiga kostnader för det allmänna, om man skulle tillämpa samma förfarande för obetydliga erkända förseelser.

Sett i ett vidare perspektiv gagnas rättssäkerheten i samhället bäst genom en ordning där domstolsförfarandet i dess mest kvalificerade former väsentligen koncentreras till de särskilt invecklade och betydelsefulla målen.

Även när det gäller handläggningen av brottmål i domstol ha sådana synpunkter varit avgörande för reglerna om domförhet. Sålunda gäller numera, enligt $1: 3 \mathrm{RB}$, att tingsrätt är domför med en lagfaren domare vid huvudförhandling och syn å stället i mål om brott för vilket icke är stadgat svårare straff än böter. I andra brottmål är tingsrätten domför med en lagfaren domare och fem (vid förfall fyra) nämndemän (1:4 RB). Lekmännens deltagande är sålunda begränsat till de något grövre brottmålen.

\section{Atalsunderlåtelse}

De grundläggande reglerna om ålalsunderlåtelse finnas — som nyss nämnts - i 20:7 RB fördelade på fyra särskilda punkter:

1. Bagatellbrottslighet. Härom gäller sedan den 1 juli 1971 , att åklagare får besluta att icke tala å brott:

om det kan antagas, att $\mathrm{i}$ händelse av lagföring annan påföljd än böter icke skulle komma att ådömas och den misstänktes lagföring ej finnes påkallad ur allmän synpunkt.

Tidigare gällde, att det skulle vara ,uppenbart“ att annan påföljd än böter icke skulle komma att ådömas. Den vidgade ramen för åtalsunderlåtelse gavs för att tillmötesgå önskemål om smidig handläggning av mindre allvarliga brott, förövade av narkotikaskadade personer över 18 år, och av övriga såsom mindre allvarliga bedömda lagöverträdelser. Åklagaren får nu rätt att unde:låta åtal, även om straffet vid lagföring skulle bliva höga böter. Om tillämpningen har riksåklagaren (RA) bl. a. uttalat (cirkılär C 67):

Allmänt kan sägas, att förutsättningar för åtalsunderlåtelse ofta föreligger vid brott som gör intryck av att vara engångsförseelser. Det kan inte gärna komma i fråga att beträffande alla förseclser särskilt 
utreda om den brottslige tidigare begått liknande förseelse. Hänsynen till allmän laglydnad leder emellertid till att även engångsförseelser inte sällan måste beivras, i förekommande fall genom strafföreläggande.

Mot bakgrund av 1968 års brottmålsutrednings betänkande om snatteri (SOU 1971:10) har regeringen nyligen genom ändring i 1964 års åklagarinstruktion bemyndigat vissa åklagare att pröva om åtal för mindre förmögenhetsbrott (8:2, 9:2 och 10:2 BrB) bör ske. Den utökade befogenheten gäller sedan den 1 april 1972 . I anslutning härtill har RA (i cirkulär C 70) bl. a. uttalat:

Meningen är att underlåtelse av åtal för i synnerhet snatteri skall förekomma i större utsträckning än hittills. ... Sammanfattningsvis kan sägas att åtal bör underlåtas om brottet vid en samlad bedömning kan anses ha ringa straffvärde. Så är i regel inte fallet om den misstänkte använt hjälpmedel eller samarbetat med andra personer. Åtalsunderlåtelse bör inte heller förekomma när omständigheterna tyder på att gärningen ingår i en serie av liknande brott eller annan kriminalitet kan föreligga. Visar tillgängliga uppgifter, att den misstänkte förut har gjort sig skyldig till förmögenhetsbrott, bör åtal inte underlåtas. Hänsyn skall dock inte tas till förhållanden som ligger långt tillbaka i tiden. Om åtalsunderlåtelse inte anses kumna meddelas, skall strafföreläggande alltid utfärdas när förutsättningar härför är för handen.

2. Seriebrottslighet. Här får åklagare underlåta åtal:

om brottet förövats, innan den misstänkte dömts för annat av honom förövat brott eller till fullo undergått straff eller annan påföljd för sådant brott, och det är uppenbart, att brottet i jämförelse med det andra brottet är med hänsyn till påföljden utan nämnvärd betydelse.

Stadgandet gäller som synes tre särskilda, vanligt förekommande fall:

a) den misstänkte har ännu icke dömts för något av brotten;

b) efter domen upptäckes, att den dömde före domen begått ytterligare brott;

c) innan den dömde till fullo undergått straff eller annan påföljd, förövar han nytt brott; t. ex. under permission eller rymning eller medan han är villkorligt frigiven eller (vid dom till ungdomsfängelse eller internering) vårdas utom anstalt.

3. Atypiska brott. Endast RÅ får i sådana sällsynta fall underlåta åtal:

om det i annat fall av särskilda skäl är uppenbart, att påföljd ej erfordras för att avhålla den misstänkte från vidare brottslighet och det med hänsyn till omständigheterna ej heller eljest är påkallat, att åtal väckes. 
En motsvarande något mera omfattande möjlighet för domstol att döma till ansvar men icke till påföljd finnes inrymd i $33: 4 \mathrm{BrB}$.

4. Brott, förövat av psylkiskt avvikande person. Åtalsunderlåtelse får ske:

om brottet uppenbarligen begåtts under inflytande av sådan själslig abnormitet, som avses i 33 kap. $2 \S$ brottsbalken, samt sluten psykiatrisk vård eller vård $\mathrm{i}$ vårdhem eller specialsjukhus för psykiskt utvecklingsstörda kommer till stånd utan lagföring och åtal ej är păkallat av särskilda skäl.

Enligt äldre rätt ansågs det tillkomma åklagare att underlåta åtal för brott, som begåtts av den som uppenbarligen skulle komma att straffriförklaras. Med BrB infördes ståndpunkten, att även gärningar av psykiskt avvikande äro brott, när kravet på uppsåt eller oaktsamhet kunde anses uppfyllt. Numera är det avgörande för beslutet i åtalsfrågan dels om förutsättningarna enligt 33:2 BrB äro för handen dels om den misstänkte frivilligt eller tvångsmässigt vårdas på psykiatriskt lasarett, vårdhem eller specialsjukhus.

Redan 1944 års lag om eftergift av åtal mot vissa underåriga innehöll utvidgade möjligheter att underlåta åtal i fråga om brott, som någon förövat efter inträde i straffmyndig ålder (15 år) men före 18 års ålder. Den ersattes av 1964 ărs lag med särskilda bestämmelser om unga lagöverträdare (LUL), som trädde i kraft samtidigt som BrB. Sedan den 1 juli 1971 har $1 \S$ LUL följande lydelse:

Har brott begåtts av någon som vid tiden för brottet ej fyllt aderton år, må, utöver vad som följer av 20 kap. $7 \S$ rättegångsbalken, åklagare besluta att ej tala å brottet

om den underårige ställes under övervakning jämlikt $26 \S$ barnavårdslagen, omhändertages för samhällsvård enligt $29 \S$ sagda lag eller blir föremål för annan därmed jämförlig åtgärd eller utan dylik åtgärd blir föremål för annan hjälp- och stödåtgärd samt det med skäl kan antagas att härigenom vidtages vad som är lämpligast för hans tillrättaförande, eller

om brottet uppenbarligen skett av okynne eller förhastande.

Åtal skall dock väckas, om det finnes påkallat ur allmän synpunkt.

Med den begränsning som följer av sista stycket har åklagaren möjlighet att underlåta åtal under två alternativa betingelser:

a) att brottet uppenbarligen skett av okynne eller förhastande. Till belysning av denna betingelse har RẢ (i cirkulär C 67) anfört:

Om brottet uppenbarligen har skett av okynne eller förhastande, kan liksom hittills åtal underlåtas även utan att särskild åtgärd vidtagits. Det måste emellertid noggrant övervägas om ett brott verkligen 
kan sägas ha skett uppenbarligen av okynne eller förhastande; så kan det i allmänhet inte anses när det är fråga om ett stort antal brott eller brottslighet som varat under en längre tidrymd. För åtalsunderlåtelse i sådana fall erfordras att någon hjälp- eller stödåtgärd vidtas.

$R \AA ̊$ varnar i denna förbindelse mot att tillgripa åtalsunderlåtelse utöver befogenheten enligt 20:7 1. RB i fråga om bötesbrott såsom trafikbrott och överträdelser av ordningsföreskrifter.

b) att den unge blir föremål för hjälp-eller stödåtgärd. Utgångspunkten är här, att åtalsunderlåtelse skall ske så snart barnavårdsnämnden vidtager den åtgärd, som är lämpligast för lagöverträdaren. Med anledning av behovet att utan formellt beslut av nämnden kunna låta den unge bliva föremål för hjälpoch stödåtgärd, utvidgades möjligheten till åtalsunderlåtelse år 1971 att omfatta även fall, där den unge har frivillig kontakt med nämnden. Man har framför allt fruktat, att ett formellt beslut om vård skulle få negativa effekter på hans inställning till vården. Stadgandena om åtalsunderlåtelse $\mathrm{i}$ BvL, NvL och AsocL avse framför allt att förhindra, att lagföring kommer till stånd, medan den misstänkte är föremål för vård och behandling i eller $\mathrm{i}$ vissa fall utom anstalt. Den som har ansvaret för vården skall i regel höras före beslutet. Begränsningar i möjligheten till åtalsunderlåtelse äro föreskrivna i NvL och AsocL.

\section{3. Åtalsprövning enligt brottsbalken}

Utöver de allmänna stadgandena om åklagares processbehörighet finnas i BrB bestämmelser, vilka åsyfta att reglera åklagares kompetens i fråga om brott, som inom riket begåtts å utländskt fartyg eller luftfartyg eller som begătts utom riket. Det faller utom ramen för denna framställning att närmare ingå på stadgandena härom i 2 kap. BrB. Det må emellertid erinras om det tillägg till 2:3 BrB, som trädde i kraft den 9 juni 1971 och gällde av utlänning utom riket förövat brott som är kapning av luftfartyg eller folkrättsbrott. Det är vidare anledning att erinra om den ändring i 2:5 $\mathrm{BrB}$, som trädde i kraft den 1 april 1972 samtidigt som 1971 års lag om straff för trafikbrott, som begåtts utomlands. I samband härmed har regeringen utfärdat nytt bemyndigande för $R \AA ̊$ att $\mathrm{i}$ vissa fall förordna, att åtal får väckas (SFS 1972:44).

Med anledning av proposition 1972:98 har riksdagen i maj 1972 med förbehåll godkänt den europeiska konventionen om brottmålsdoms internationella rättsverkningar men till höstsessionen uppskjutit frågor om bl. a. ändringar i 2 kap. BrB.

Av långt större praktiskt intresse äro strävandena att skapa nya regler om beivrande av vissa brott, begångna av utlänningar. Efter mordet på den jugoslaviske ambassadören i Stockholm i april 1971 uppdrogs åt åtalsrättskommittén (Riksdagsberättelsen 
år 1971, Ju:55) att komma med förslag till bestämmelser om förenklat förfarande för beivrande av brott av utlänning, som skall avlägsnas ur riket. Åtalsrättskommittén har därefter i en promemoria (Stencil Ju 1971:14) framlagt förslag till lag med vissa bestämmelser om beivrande av utlännings brott. Förslaget tar sikte på sådana fall då det på grund av föreliggande dom om förvisning eller beslut om utvisning eller förväntan om sådan dom eller sådant beslut är klart, att utlänningen skall avlägsnas ur riket. Med vissa begränsningar föreslás åklagaren få befogenhet att besluta om åtalsunderlåtelse, ja rent av om inställande av förundersökning. Vidare föreslås domstolarna få vidgade möjligheter att i sådana fall ge utlänning villkorlig dom. Kommitténs förslag har ännu icke lett till proposition i ämnet.

Under de successiva reformerna av 1864 års strafflag infördes i fråga om förmögenhetsbrotten rätt för åklagare att pröva huruvida sådant brott (se 8:13, 9:12 och 10:10 BrB) förövat mot nära anhörig mot offrets önskan påkallade åtal ur allmän synpunkt. Med BrB infördes mera generella former av åtalsprövning i fråga om brotten mot person. Man brukar benämna den prövning som sker ur allmän synpunkt för lämplighetsprövning och den som dessutom kräver särskilda skäl till åtal för kvalificerad lämplighetsprövning, och lagstiftningen uppvisar rika variationer (se t. ex. $3: 11,5: 51$ och $6: 11 \mathrm{BrB}$ ) med eller utan anknytning till angivelse från målsägandens sida. I fråga om olovligt förfogande $(10: 4 \mathrm{BrB})$ över avbetalningsgods har man alltsedan 1934 försökt olika lagtekniska lösningar för alt begränsa säljarens möjlighet att påkalla myndigheternas medverkan till inskridande mot köpare, som icke längre kunna tillhandahålla godset. Den nu gällande särskilda åtalsregeln i 10:10 andra stycket BrB föreskriver sålunda kvalificerad lämplighetsprövning:

Olovligt förfogande över egendom, som kommit i gärningsmannens besittning genom avtal, enligt vilket äganderätten skall övergå först sedan betalning erlagts, må ej åtalas av ăklagare, med mindre åtal av särskilda skäl finnes påkallat ur allmän synpunkt.

Riksåklagaren har ifrågasatt införandet av en ny variation av lämplighetsprövning vid otukt med syskon (6:5 BrB), nämligen att sådant brott ej får åtalas med mindre särskilda skäl talar däremot (AD 1587-69). Justitieminister Lennart Geijer har i direktiven till utredningen för översyn av sedlighetsbrotten (den 19 november 1971) lämnat öppet huruvida brottstypen behöver bibehållas eller om en särskild åtalsregel skall införas.

Såsom redan inledningsvis anförts anses det numera vara klart, att man för användning av de särskilda åtalsreglerna i BrB icke behöver företaga en fullständig brottsutredning. Med anledning av motioner anförde riksåklagarämbetet i utlåtande till första lagutskottet vid 1960 års riksdag, att för ett avskrivnings- 
beslut icke kan uppställas kravet på att utredning skall föreligga om att brott verkligen förekommer. I anslutning härtill anförde utskottet (utlåtande nr 28) efter att ha redogjort för tveksamheten om utredningsförfarandet, att "någon vägande invändning icke synes kunna riktas mot ämbetets förevarande ståndpunkt", och att ämbetet borde ge sina synpunkter till känna. Så skedde genom cirkulär nr 96. Av det sagda framgår, att åtalsprövningen bör ske i form av beslut om åtal eller om avskrivning av målet.

\section{Rapporteftergift}

Från instruktioner till polismästarna i de största städerna har polisens rätt att meddela rapporteftergift överflyttats till $14 \S \mathrm{PI}$, som efter den 1 april 1972 lyder sålunda:

Får polisman kännedom om brott som hör under allmänt åtal skall han avge rapport därom till vederbörande förman så snart det kan ske.

Är för brott ej stadgat svårare straff än böter och ej heller normerade böter och är brottet med hänsyn till omständigheterna $\mathrm{i}$ det särskilda fallet obetydligt, äger polisman underlåta att avge rapport eller att vidarebefordra rapport till åklagare och i stället låta saken bero vid påpekande eller erinran till den felande.

Är brott som avses i 8 kap. $2 \$$ brottsbalken med hänsyn till det tillgripnas värde och övriga omständigheter obetydligt, äger polisman som är förundersökningsledare underlåta att vidarebefordra rapport till åklagare och i stället lăta saken bero vid erinran.

Rapporteftergiften är omedelbar, när den meddelas direkt pă platsen till den felande. Rapporteftergift kan också meddelas $i$ efterhand sedan viss utredning företagits och saken prövats av polisman i befälsställning eller vid snatteri polisman som i egenskap av undersökningsledare leder förundersökningen. Samhällsingripandet kan vid omedelbar rapporteftergift inskränka sig till ett påpekande. Vid rapporteftergift $\mathrm{i}$ efterhand för snatteri måste man tillgripa erinran.

När möjligheten att meddela rapporteftergift i efterhand för snatteri infördes, utfärdade regeringen samtidigt ett cirkulär till polismyndigheterna (SFS 1972:25) med anvisningar för tillämpningen av det nya stadgandet. Av dessa framgår, att tillgreppet skall ha skett $i$ en affärslokal, att värdet av det tillgripna inte bör vara högre än ett försäljningspris på omkring 20 kronor och att ersättningsanspråk ej förekommer. Har den misstänkte förut gjort sig skyldig till förmögenhetsbrott av liknande eller allvarligare slag, bör rapport i allmänhet avges. Detsamma gäller, när tillvägagångssättet varit särskilt förslaget eller andra försvårande omständigheter framkomma. Erkännande behöver icke föreligga. Det måste dock stå klart för polismannen, att den misstänkte har begått gärningen och att han haft uppsåt att olovligen tillägna sig varan, även om han förnekar tillägnelseuppsåt. 
I anslutning till ändringen i PI och cirkuläret har rikspolisstyrelsen (RPS) utfärdat närmare anvisningar (Allmänna meddelanden $\mathrm{nr}$ 6/72 notis $\mathrm{nr}$ 133). När rapporteftergift i efterhand meddelas, skall den felande snarast underrättas om beslutet, om han är närvarande muntligen eljest skriftligen. Den misstänkte registreras i det lokala personregistret och beslutet redovisas till RPS.

\section{Summariska strafförfaranden}

Som summariska strafförfaranden betecknas här strafföreläggande, ordningsföreläggande och anmaning att betala parkeringsbot.

Med RB, som trädde i kraft år 1948, infördes i begränsad omfattning möjlighet för åklagare att i stället för att väcka åtal för brottet förelägga den misstänkte att godkänna det bötesstraff, som åklagaren ansett brottet förskylla. Om strafföreläggande stadgas numera i 48:4 RB följande:

Strafföreläggande får utfärdas beträffande brott, för vilket ej stadgas svårare straff än böter och ej heller normerade böter och vilket, om dagsböter stadgas, finnes förskylla högst femtio dagsböter eller, jämte annat brott, högst sextio dagsböter som gemensamt straff.

Konungen äger förordna, att strafföreläggande får utfärdas även beträffande brott, för vilket stadgas dagsböter eller fängelse i högst sex månader men vilket $\mathrm{i}$ övrigt är sådant som anges $\mathrm{i}$ första stycket.

Genom en med stöd av stadgandet utfärdad kungörelse har strafföreläggande fått ett användningsområde långt utanför de rena bötesbrotten. Såsom redan angivits, rekommenderar RÅ dess användning vid bl. a. de mindre förmögenhetsbrott, där åtalsunderlåtelse ej kan ifrågakomma.

Genom ändring i 48 kap. RB, som trädde i kraft den 1 juli 1968, överfördes med vissa ändringar dit bestämmelser från 1966 års lag om föreläggande av ordningsbot, vilken först försöksvis tillämpats i vissa delar av landet. Om ordningsföreläggande gäller enligt 48:13 första stycket RB:

Föreläggande av ordningsbot får utfärdas beträffande brott, för vilket ej stadgas annat straff än böter omedelbart i penningar och ej heller normerade böter och för vilket ordningsbot bestämts på sätt föreskrives i $14 \S$.

Enligt 48:14 RB äger regeringen meddela föreskrifter om det högsta belopp, till vilket ordningsbot får bestämmas, och om andra begränsningar. RÅ företager i samråd med RPS urval av de brott som skall ifrågakomma och RÅ bestämmer för olika brott de belopp som skola upptagas. De närmare föreskrifterna om föreläggande av ordningsbot finnas i en kungörelse och ett av RÅ träffat beslut. 
Med 1960 års lag om parkeringsbot, som pá försök först tillämpades i delar av landet, skapades nya former för handläggningen av det ökande antalet överträdelser av föreskrifter rörande parkering eller annan uppställning eller stannande av fordon. Gemensamt för sådana föreskrifter är, att straffet är böter omedelbart i penningar. För ordningsbot är bötesbeloppet bestämt inom ramen 10-100 kronor. Anmaning att betala parkeringsbot kan överlämnas direkt till föraren eller fästas på fordonet av polisman eller trafikövervakare. Genom ändring år 1970 i 67 § 1951 års vägtrafikförordning kan ägaren i allmänhet ställas till ansvar, om det ej är utrett vem som förde fordonet. Närmare föreskrifter rörande ordningsbot finnas i en kungörelse och ett av RÅ meddelat beslut.

Enligt 48:3 RB gäller godkänt strafföreläggande och föreläggande av ordningsbot som dom som vunnit laga kraft. Betalning av böterna anses enligt 48:11 och $17 \mathrm{RB}$ i princip innefatta godkännande. Underlåter den misstänkte att godkänna föreläggandet, får åklagaren taga ställning till frågan, huruvida åtal skall väckas. Har föreläggandet godkänts men betalningen uteblivit, går ärendet till indrivning.

Har parkeringsbot betalats, kan återbetalning ske efter beslut i vissa fall av RPS och i andra fall av polismyndigheten. Utebliven betalning ger i första hand anledning till föreläggande av ordningsbot.

\section{Avkriminalisering av bagatellbrottsligheten}

Som alternativ till alla de ovan redovisade metoderna att befria domstolarna från handläggningen av den rena bötesbrottsligheten brukar man uppställa frågan om avkriminalisering. Sålunda föreslog parkeringskommittén (SOU 1968:18) att uppställning av fordon i strid med lokal föreskrift i regel endast skulle medföra skyldighet att till kommunen erlägga fastställd kontrollavgift. Fylleristraffutredningen (SOU 1968:55 och 56) föreslog upphävande av bestämmclserna om fylleri (16:15 och 21:15 BrB) och ny lagstiftning om omhändertagande och behandling av berusade personer. Vad kommittén och utredningen föreslagit har ännu icke lett till något.

Skattestrafflagutredningen (SOU 1969:42) framlade ett förslag, varigenom man i stället för bötesstraff skulle begagna avgifter för vissa försummelser att administreras av skattemyndigheterna. Förslaget vann i denna del regeringens och riksdagens bevågenhet. I 1956 års taxeringsförordning och en rad andra skatte- och avgiftsförfattningar infördes bestämmelser som trädde i kraft den 1 januari 1972, om skatte- och avgiftstillägg för oriktig skriftlig uppgift och förseningsavgift för underlåtenhet att i tid avgiva skriftlig uppgift. Dessa tillägg och avgifter skola 
utgå även om varken uppsåt eller oaktsamhet kan läggas den felande till last men får eftergivas av myndigheten.

\section{Domstolarnas insats i straffrättskipningen}

Det är uppenbart, att tillämpningen av samtliga ovan redovisade stadganden, varigenom mål och ärenden om brott och lagbrytare i stor utsträckning avgöras i administrativ ordning, i hög och åsyftad grad inverkat och inverkar på tillströmningen av brottmål till de allmänna domstolarna. Tingsrätterna ha därigenom undgått att belastas med handläggningen av ett otal rena bötesmål. Man har även undandragit dem bedömningen av ett betydande antal mål, där ådömande av svårare påföljd än böter kunde ha aktualiserats. Det är mycket svårt att mäta de förändringar som åstadkommits med sådana medel dels därför att statistiken är inkongruent och bristfällig dels därför att man alls icke kan bedöma, om brott i samma grad kommit till myndigheternas kännedom under en längre period dels därför alt man icke gjort sig någon samlad bild av förändringar i lagstiftningen under samma tid.

Redan inom det korta perspektiv, som tiden efter BrBs ikraftträdande år 1965 ger kan man se en betydande nedgång i antalet brottmål i första instans. De ha här fördelats mellan enmansmål (endast den lagfarne domaren) och mål med stor eller liten nämnd enligt domförhetsreglerna före den 1 januari 1970 (för år 1970 har en uppskattning skett).

\begin{tabular}{lcccccc} 
Brottmål & 1965 & 1966 & 1967 & 1968 & 1969 & 1970 \\
Enmansmål & 37.700 & 45.134 & 59.732 & 56.874 & 33.951 & 25.069 \\
Liten nämnd & 50.420 & 48.612 & 42.178 & 39.318 & 34.914 & 37.753 \\
Stor nämnd & 17.058 & 19.537 & 21.197 & 22.149 & 22.263 & 22.306 \\
\hline Samtliga & 105.179 & 113.284 & 123.126 & 118.387 & 91.118 & 85.118
\end{tabular}

Man har anledning att anlaga, att minskningen av enmansmålen beror på en ökad användning av summariska strafförfaranden. ökningen av stornämndsmålen kan återspegla ökningen av den grövre brottsligheten under samma period. I viss utsträckning kunna antydda förhållanden belysas med uppgifter

Personer

Ej till ansvar dömda

Ej till påföljd dömda därav enligt $33: 2 \mathrm{BrB}$ därav enligt $33: 4 \mathrm{BrB}$ Dömda till böter Dömda till svårare påföljd

$\begin{array}{rrrrrr}1965 & 1966 & 1967 & 1968 & 1969 & 1970 \\ 5.157 & 5.235 & 5.843 & 5.691 & 5.332 & 5.122 \\ & & & & & \\ 35 & 40 & 15 & 16 & 17 & 13 \\ 52 & 55 & 55 & 52 & 90 & 52 \\ 89.117 & 94.128 & 102.412 & 94.660 & 67.825 & 61.721 \\ 21.423 & 24.293 & 26.434 & 27.880 & 26.620 & 27.330 \\ 15.784 & 123.751 & 134.757 & 128.299 & 99.884 & 94.238\end{array}$


om antalet personer, som under samma period förekommit i brottmål inför domstolarna.

Som förklaringar till ökningen av den grövre brottsligheten har man brukat anföra dels ökningen av grova trafikbrott (särskilt rattfylleri) dels ökningen av antalet utländska lagöverträdare.

\section{De summariska strafförfarandenas inverkan}

En översikt av de summariska förfarandenas omfattning under motsvarande period klarlägger deras betydelse för domstolarnas verksamhetsfält i fråga om bötesbrottsligheten. Här nedan redovisas antalet inbetalda parkeringsböter och antalet godkända strafförelägganden och förelägganden av ordningsbot.

\begin{tabular}{lccrrrc} 
Art & 1965 & 1966 & 1967 & 1968 & 1969 & 1970 \\
Parkeringsbot & 265.624 & 319.234 & 374.487 & 461.642 & 421.803 & 464.902 \\
Ordningsföreläggande & - & - & 36.974 & 87.288 & 178.686 & 150.434 \\
Strafföreläggande & 226.147 & 279.595 & 292.826 & 227.826 & 127.690 & 122.516 \\
\hline Samtlige & 511.771 & 698.819 & 704.365 & 776.806 & 728.179 & 737.852
\end{tabular}

Av tabellen framgår, att föreläggande av ordningsbot numera har övertagit ganska många bötesmål, som tidigare handlades med strafföreläggande. Att så skett beror bl. a. på ändringar i straffbestämmelserna från dagsböter till penningböter.

\section{9. Åtalsunderlåtelsernas inverkan}

Vid en redovisning av åtalsunderlåtelserna under samma period har man möjlighet att urskilja ungdomsfängelseelevernas seriebrottslighet (uf) från andras. I fråga om åtalsunderlåtelse enligt LUL och BvL har man kunnat uppskatta fördelningen mellan grövre och lindrigare brott. Åtalsunderlåtelse enligt NvL avser huvudsakligen fylleri $(16: 15 \mathrm{BrB})$.

\begin{tabular}{|c|c|c|c|c|c|c|}
\hline Lagrum & 1965 & 1966 & 1967 & 1968 & 1969 & 1970 \\
\hline 20:7 RB 1 . & 8.254 & 9.784 & 9.680 & 6.572 & 5.298 & 4.616 \\
\hline 2. (uf) & 691 & 585 & 536 & 585 & 606 & 58 \\
\hline (övriga) & . & . & ․ & 3.904 & 4.492 & 4.4 \\
\hline 3. & 3 & 4 & 4 & 8 & 9 & \\
\hline 4. & 628 & 717 & 780 & 755 & 826 & \\
\hline LUL grövre & 3.052 & 3.521 & 3.763 & 4.277 & 4.656 & 5.0 \\
\hline lindrigare & 2.879 & 2.490 & 2.409 & 2.431 & 2.796 & 2.6 \\
\hline vL grövre & 1.292 & 1.518 & 1.717 & 1.762 & 1.945 & 1.8 \\
\hline lindrigare & 535 & 436 & 505 & 465 & 506 & 4 \\
\hline NvL & 9.654 & 10.972 & 10.633 & 9.816 & 6.769 & 5.5 \\
\hline
\end{tabular}


Såsom framgår av de meddelade uppgifterna ha domstolarna under den ifrågavarande perioden i ökad omfattning befriats från befattningen med grövre brott, förövade av ungdom. Det kan tilläggas, att narkotikabrottsligheten medförde åtalsunderlåtelse för grövre brott år 1969 för 462 personer och 1970 för 248 personer. Det är all anledning att vänta, att åtalseftergift enligt 20:7 1. RB efter lagändringen kommer att öka redan under andra halvåret 1971 och att ökningen kommer att avse väsentligen grövre brott.

\section{0. Åtalsprövningens inverkan}

Statistiska uppgifter saknas om omfattningen och inriktningen av tilllämpningen av de särskilda åtalsreglerna i 3-10, kap. BrB. Man har emellertid anledning att förmoda, att åklagarna redan på grund av arbetsbelastningen i övrigt i alltmera ökad omfattning och på allt tidigare stadium meddela avskrivningsbeslut.

\section{Rapporteftergifternas inverkan}

Icke heller på delta område finnas några statistiska uppgifter. Av allt att döma ökar omfattningen av rapporteftergifter i efterhand och ökningen väntas stiga med sådana rapporteftergifter för snatterier i affärslokaler.

\section{Den misstänktes ställning}

Såsom framgått av redovisningen av förutsättningarna för meddelande av beslut om åtalsunderlåtelse eller avskrivning och beslut om rapporteftergift öppnar man numera möjlighet för myndigheten att besluta på grundval av sin egen bedömning av gärningens brottslighet och gärningsmannens skuld. Även om den misstänkte gör invändningar om vad som har förevarit och bestrider t. ex. tillägnelseuppsåt, kan beslutet fattas. Naturligtvis ankommer det på myndigheten att i sådana fall företaga en mera försiktig bedömning än eljest, men det torde icke kunna undgås, att fall inträffa, där den misstänkte känner sig orättvist behandlad. När han underrättas om beslutet och om dess betydelse i registreringshänseende, torde han icke ha annan möjlighet att vinna rättelse än genom att påkalla överprövning av beslutet och därigenom försöka förmå överordnad myndighet att återkalla det eller föranstalta om åtal.

För det stora flertalet misstänkta erbjuder systemet med administrativt avgörande av brottmålet betydande fördelar. Beslutet träffas utan någon offentlighet och i regel i nära anslutning till brottet eller dess upptäckt. När summariskt strafförfarande ifrågakommer, är bötesstraffet $\mathrm{i}$ allmänhet måttligt. Om betydelsen av registreringen för bedömning av ny brottslighet vet den misstänkte föga eller intet. 


\section{Målsägandens ställning}

Såsom kortfattat antytts i fråga om åtalsprövning enligt $\mathrm{BrB}$ kommer målsägandens inställning till åtalsfrågan att få viss betydelse dels vid vissa förmögenhetsbrott mot nära anhörig dels i fråga om några andra brott (t. ex. enligt 3:11 tredje stycket och $5: 5$ första stycket $\mathrm{Br} B)$. Om målsägandens rätt att själv väcka åtal för brott eller att biträda åtalet stadgas i 20:8 RB och om hans rätt att övertaga åtalet finnes en bestämmelse i 20:9 RB. I 21 kap. RB finnas bestämmelser om enskilt anspråk på grund av brott. Vidare finnes i $21 \S$ första stycket 1947 års förundersökningskungörelse en föreskrift om skyldighet att underrätta målsäganden eller den som övertagit hans anspråk om nedläggande av förundersökning eller beslut att talan ej skall väckas. I det ovan omnämnda cirkuläret on rapporteftergift för vissa snatteribrott har regeringen föreskrivit, att det skall vara utrett, att den som lidit skada av tillgreppet har fått ersättning eller avstår från att rikta ersättningsanspråk mot den misstänkte.

Sedan den 1 juli 1971 finnes viss möjlighet att av statsmedel få ersättning för personskada, som icke ersatts av gärningsmannen. Under de tre första kvartalen av budgetåret har endast 32.000 kronor tagits i anspråk för detta ändamål.

Avgöres icke ersättningsanspråk på grund av brott i brottmålet, får talan föras särskilt. Enligt förslaget till lag om rättegången i mindre brottmål (Ds Ju 1972:6) avses även talan om skadestånd under $3.500 \mathrm{kr}$ få föras förenklat.

\section{Allmänhetens insyn i samhällsingripandena}

Enligt åklagarinstruktionen skall RÅ ägna särskild uppmärksamhet åt tillämpningen av gällande bestämmelser om beslut att ej tala å brott och om strafföreläggande, och länsåklagarna skola verka för att bestämmelserna om beslut att ej tala å brott och om annan särskild åtalsprövning samt om strafföreläggande tilllämpas riktigt och enhetligt. RÅ fullgör sin uppgift, såsom visats, genom cirkulär och dessutom genom regelbundna inspektioner. RPS och länspolischeferna utöva på motsvarande sätt tillsyn över tillämpningen av bestämmelsen om rapporteftergift. På båda verksamhetsområdena är alltså kontrollen av tillämpningen intern och sker utan allmänhetens insyn i det enskilda fallet.

Rättegången i brottmål är i princip offentlig även när rättskipningen i de rena bötesmålen utövas av den lagfarne domaren ensam. Däremot torde det höra till undantagen, att målen uppmärksammas.

Såsom framgår av den statistiska redovisningen har lekmännens deltagande i straffrättskipningen blivit av relativt sett allt mindre omfattning. Av alla brottmål, inalles måhända långt över en miljon, handläggas vid de allmänna domstolarna i första instans (tingsrätterna) endast omkring 60.000 av domare och 
nämnd. I de högre instanserna finnes alls ingen lekmannamedverkan, men regeringen överväger att införa nämnd i hovrätterna. Lekmannainflytandet berör sålunda bara en liten del av brottmålen men samtidigt alla mål, där påföljden kan bliva svårare än böter. På så sätt har man förverkligat intentionen, att endast betydelsefulla och invecklade mål skulle föras till domstolarna och där avgöras under medverkan av lekmän.

\section{Några sammanfattande synpunkler}

Under min verksamhet har det ofta slagit mig, att det stora och praktiskt betydelsefulla rättsområde, som jag här i korthet har beskrivit, i så liten omfattning blivit föremål för framställningar i läroböckerna och undersökningar av rättsvetenskaplig art. Ännu märkligare är det, att man i den rätitspolitiska debatten icke kunnat få fram något individuellt eller partipolitiskt intresse för frågor om handläggningen av mål och ärenden, där samhällets straffanspråk och enskilds rätt prövas.

Det kan vara anledning att ägna någon uppmärksamhet åt många frågor, av vilka här blott enstaka kunna antydas:

1. Är det lyckligt, att brottmảl i allt högre grad avgöras av myndighet enligt direktiv från regeringen eller överordnad myndighet?

2. Är det lyckligt, att lekmäns medverkan i rättskipningen begränsas till betydelsefulla och invecklade mål?

3. Är det lyckligt, att en sådan utveckling styres av samhällets önskan att $i$ allt större omfattning utöva kontroll av medborgarnas beteenden genom straffbestämmelser, vilka skapa utrymme för särskilda funktionärgruppers myndighetsutövning?

4. Är det lyckligt, att målsägandens ställning alltmera försvagas? 5. Är det lyckligt, att beslut, varigenom myndighet tillkännager sin bedömning av den enskildes straffrättsliga ansvar, träffas på grundval av ett allt mindre utredningsmaterial?

6. Är det lyckligt, att myndighets beslut i allt större omfattning registreras för att i framtiden kunna begagnas mot den enskilde?

\section{En efterskrift om fullbordanspunkten vid tillgrepp}

I dom den 2 juni 1972 (DB 15) har Högsta domstolen (justitieråden Joachimsson, Gyllensvärd, Holmberg och Ulveson; Riben dissident) intagit den ståndpunkten, att fullbordat tillgreppsbrott föreligger först när en vara, som kunden själv får taga och medföra till kassa eller expedit, förts ut från butiken, eller, i fråga om varuhus med klart avgränsade avdelningar, från avdelningen.

Försök till snatteri är ej straffbart (8:2 och $12 \mathrm{BrB})$. 